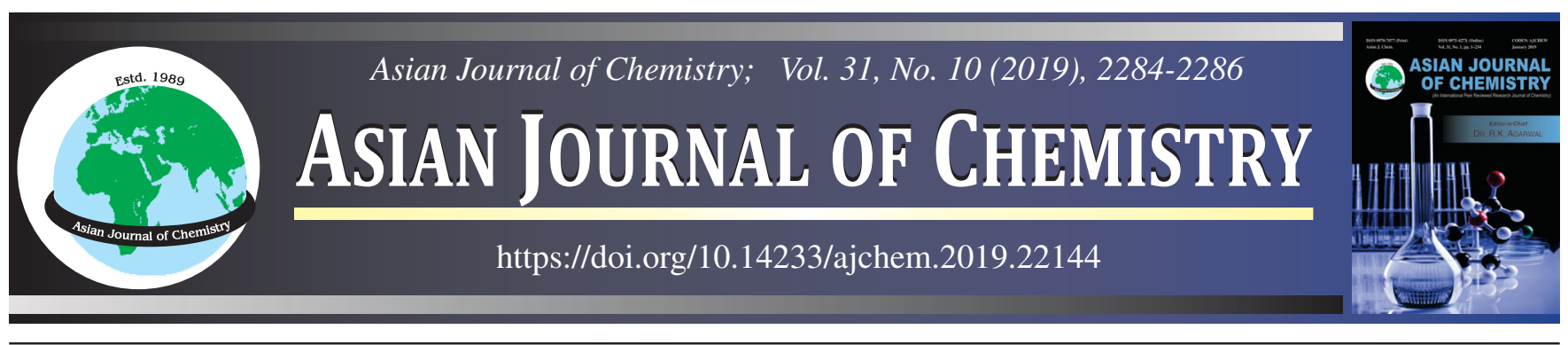

\title{
Chemical Composition and Evaluation of Antibacterial Activities of Essential Oil from Lemon (Citrus aurantifolia L.) Leaves Growing Tien Giang Province, Vietnam
}

\author{
Tan Phat Dao ${ }^{1,2, *}$, Thien Hien Tran ${ }^{1,2}$, Phu Thuong Nhan Nguyen ${ }^{1}$, Tran Thi Kim NGan ${ }^{1}$, Ngo Thi Cam Quyen ${ }^{1}$, \\ Trieu Tuan Anh ${ }^{3}$, Pham Minh Quan ${ }^{4}$, Trinh Thi Thu Huong ${ }^{4}$ and Ngoc Hoi NguYen ${ }^{5}$
}

${ }^{1}$ Center of Excellence for Biochemistry and Natural Products, Nguyen Tat Thanh University, Ho Chi Minh City, Vietnam ${ }^{2}$ NTT Hi-Tech Institute, Nguyen Tat Thanh University, Ho Chi Minh City, Vietnam ${ }^{3}$ Faculty of Chemical Engineering and Food Technology, Nguyen Tat Thanh University, Ho Chi Minh City, Vietnam ${ }^{4}$ Institute of Natural Products Chemistry, Vietnam Academy of Science and Technology, Hanoi, Vietnam ${ }^{5}$ Institute of Applied Materials Science, Vietnam Academy of Science and Technology, 01 TL29, District 12, Ho Chi Minh City, Vietnam

*Corresponding author: E-mail: dtphat@ntt.edu.vn

Chemical compounds from essential oils have been receiving a great deal of public attention owing to a myriad of functions, including their role as a substitute for artificial preservatives. This study reports the physico-chemical characteristics and the antibacterial activities of the essential oil isolated from the leaves of lemon (Citrus aurantifolia L.) grown in Tien Giang Province, Vietnam. The essential oils were obtained by microwave assisted hydro-distillation and their chemical composition was investigated by GC-MS. The result | revealed that the oil is extremely rich in $\alpha$-citral, reaching the content of $27.982 \%$, followed by $\beta$-citronellol and D-limonene at 20.06 and $15.732 \%$, respectively. Besides, antibacterial activities of extracted essential oil against 4 bacterial cultures i.e., Pseudomonas aeruginosa, Escherichia coli, Staphylococcus aureus and Bacillus cereus was examined, highlighting strong antibacterial properties of citral in the oil.

|

Keywords: Essential oils, Lemon (Citrus aurantifolia) leaves, Chemical composition, Antibacterial activities.

ᄂ

\section{INTRODUCTION}

Plants, like herb, play a vital role in the daily life of human due to high economic and medicinal value which are mainly applied in food industry, cosmetics and folk medicine [1-6]. Citrus aurantifolia $\mathrm{L}$., is a small citrus fruit that belongs to the family Rutaceae which cultivated mainly in tropical and subtropical countries. There are different secondary plant metabolites in Citrus aurantifolia L. plants including terpenoids, flavonoids and coumarins. Moreover, lemon has various bioactive components such as flavonoids, minerals, ascorbic acid, citric acid, etc. [7-10]. Essential oils can be obtained from roots, stems, leaves and flowers of the plant which is applied for different applications such as pathogen inhibition, insect control and aromatherapy. The previous study demonstrates that aromatic and medicinal plants have antibacterial, anti-inflammatory, antiviral, antioxidant activities. Several chemical molecules of biosynthesis constitute essential oils [11-15]. These molecules are different according to the nature of the plant and the ground in which the plant is growing, the period of harvest, the studied part of the plant, the preparation of the sample, as well as the method of extraction [16-20].

Citrus essential oils consisted a complex mixture of 400 constituents (15\% non-volatile components and 86-99\% volatile) $[21,22]$. Essential oils have volatile properties at room temperature without decomposition including hydrocarbons, flavonoids, fatty acids, coumarins, waxes, carotenoids and psoralens. The previous research illustrates that the main component in Citrus essential oil was $\alpha$-pinene, limonene, p-cymene, and other aromatic compounds [23-25]. Japanese lemon leaf oil consisted of geranial as the main component, followed by limonene and neral [26]. It was reported that caryophyllene was the main component in Egyptian lemon leaf oil, followed by linalool, nerol and limonene [27]. While, Italian, Turkish

This is an open access journal, and articles are distributed under the terms of the Attribution 4.0 International (CC BY 4.0) License. This license lets others distribute, remix, tweak, and build upon your work, even commercially, as long as they credit the author for the original creation. You must give appropriate credit, provide a link to the license, and indicate if changes were made. 
and Chinese lemon leaf oils included limonene, followed by $\beta$-pinene and geranial [28,29]. Moreover, the antioxidant potentials and antimicrobial of lemon leaf essential oil have been previously described [30,31]. Although it is known that limonene is often the main constituents in lemon leaf oils, the composition of essential oils are variable by different localities. It is also reported that genetic, environmental and experimental factors could both qualitatively and quantitatively influence the distilled essential oil [32]. However, studies on chemical composition and antibacterial activities of essential oil derived from Lemon (Citrus aurantifolia L.) leaves have been lacking. As an attempt to fill this gap, the present study aims to determine the volatile constituents of essential oils from the leaf of lemon cultivated in Vietnam using GC-MS. Furthermore, antibacterial activities of essential oils against Gram-negative and two Gram-positive bacteria including Staphylococcus aureus, Escherichia coli, Pseudomonas aeruginosa and Bacillus cereus are investigated.

\section{EXPERIMENTAL}

Plant samples: Lemon (Citrus aurantifolia) leaves were collected in March 2019 from Tien Giang Province, Vietnam. After transportation to the laboratory, lemon leaves are gingerly picked, washed, ground by grinding equipment (Sunhouse SHD4322, 200W, Vietnam) and distilled directly by steam.

Through the experimental process, the extraction oil was obtained by microwave-assisted extraction $(3 \mathrm{~mL} / \mathrm{g}$ of water and material ratio, $500 \mathrm{~W}$ of microwave power and $807 \mathrm{~min}$ of extraction time) with the extraction yield $0.762 \%$.

GC-MS analysis: The composition of the essential oils of all samples was determined via gas chromatography-mass spectrometry (GC-MS). First, $25 \mu \mathrm{L}$ of sample of essential oil was mixed in $1.0 \mathrm{~mL}$ of $n$-hexane. The instrument is GC Agilent 6890N, coupled with MS 5973 inert with HP5-MS column and head column pressure of 9.3 psi. GC-MS system was performed following conditions: carrier gas $\mathrm{He}$; flow rate $1.0 \mathrm{~mL} /$ min; split 1:100; injection volume $1.0 \mu \mathrm{L}$; injection temperature $250{ }^{\circ} \mathrm{C}$; oven temperature progress included an initial hold at $50^{\circ} \mathrm{C}$ for $2 \mathrm{~min}$, then increased by $2^{\circ} \mathrm{C} / \mathrm{min}$ to $80^{\circ} \mathrm{C}$ and increased by $5^{\circ} \mathrm{C} / \mathrm{min}$ to $150^{\circ} \mathrm{C}$, continue rising to $200^{\circ} \mathrm{C}$ at $10^{\circ} \mathrm{C} /$ min and rise to $300^{\circ} \mathrm{C}$ at $20^{\circ} \mathrm{C} / \mathrm{min}$ for $5 \mathrm{~min}$.

Anti-bacterial activity: Two Gram-positive bacteria species including Staphylococcus aureus and Bacillus cereus and two Gram-negative species including Pseudomonas aeruginosa and Escherichia coli are used in this study. The agar-well diffusion assays evaluated antibacterial activity. First, the agar plates were prepared with $10 \mathrm{~mL}$ of lysogeny broth (LB) solution. Following that $3 \mathrm{~mL}$ of liquid cultures were incubated at 37 ${ }^{\circ} \mathrm{C}$ with aeration (150 rpm) overnight on LB. Second, $5 \mathrm{~mm}$ wells are cut into the surface of LB agar, and the wells were loaded with $20 \mu \mathrm{L}$ of essential oils which was incubated at 37 ${ }^{\circ} \mathrm{C}$ overnight. Finally, electronic calipers were used to measure the diameters of any clear zones around the antibacterial containing wells. The inhibition zone (IZ) is determined as the ratio between the halo diameter $(\mathrm{mm})$ and the size of disk $(5 \mathrm{~mm})$. In this case, amoxicillin $(100 \mu \mathrm{g} / \mathrm{mL})$ and sterile water act as the positive and negative control, respectively.

\section{RESULTS AND DISCUSSION}

Chemical composition of the essential oil from Lemon (Citrus aurantifolia L.) leaves: Fig. 1 shows the result of chromatography of lemon leaves essential oil and Table-1 illustrates the chemical composition of the obtained oil. Overall, 9 components were identified in the Vietnamese lemon leaves oils. The major components were $\alpha$-pinene $(27.982 \%)$ and $\beta$ citral $(20.06 \%)$. Previous studies showed that $\alpha$-citral, $\beta$-citral might modulate inflammatory processes and DNA damage $[33,34]$, which is followed by D-limonene, acetic acid, nerol, nerol acetate, citronellol and caryophyllene oxide at 15.73, $6.36,4.41,3.49,2.193$ and $2.01 \%$, respectively. Besides geographical location differences, the season of harvest and plant age, the abundance of citral constituent could be due to the influence of microwave irradiation, which causes oxygen containing polar molecules, such as water and citral molecules, to spin rapidly.

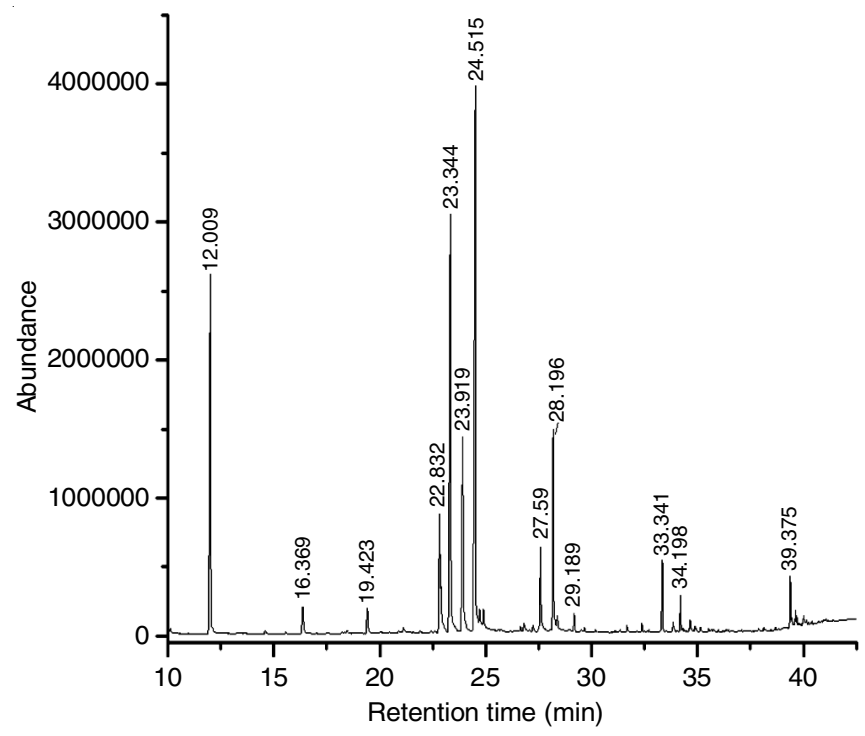

Fig. 1. GC-MS chromatogram of essential oil

\begin{tabular}{|c|c|c|}
\hline \multicolumn{3}{|c|}{$\begin{array}{c}\text { TABLE-1 } \\
\text { RESULTS OF GC-MS ANALYSIS OF } \\
\text { INGREDIENTS IN LEMON LEAVES OIL }\end{array}$} \\
\hline Retention time (min) & Constituent & Percent \\
\hline 12.090 & D-Limonene & 15.732 \\
\hline 12.072 & Unknown* & 0.381 \\
\hline 16.369 & Linalol & 1.386 \\
\hline 19.423 & Citronellal & 1.141 \\
\hline 22.832 & Nerol & 4.411 \\
\hline 22.863 & Citronellol & 2.193 \\
\hline 23.344 & $\beta$-Citral & 20.059 \\
\hline 23.919 & Unknown* & 9.428 \\
\hline 24.515 & $\alpha$-Citral & 27.982 \\
\hline 24.724 & Unknown* & 1.169 \\
\hline 24.902 & Unknown8 & 1.066 \\
\hline 27.590 & Nerol acetate & 3.494 \\
\hline 28.196 & Acetic acid & 6.356 \\
\hline 29.189 & Caryophyllene & 0.552 \\
\hline 33.310 & Unknown* & 0.464 \\
\hline 33.341 & Caryophyllene oxide & 2.008 \\
\hline 34.198 & Ent-Spathulenol & 0.973 \\
\hline 39.374 & Unknown* & 1.202 \\
\hline
\end{tabular}


Antibacterial activities of the essential oil from Lemon (Citrus aurantifolia L.) leaves: Table-2 presented the results of antibacterial properties of lemon leaves oil on the four tested bacteria species. The antibacterial activities of the essential oil on bacterial strains in ascending order include $S$. aureus $<$ E. coli $<P$. aeruginos $a$ B . cereus with the respective diameter size of $11.33 \pm 2.08,13.67 \pm 2.52,14 \pm 2.65$ and $42 \pm 2.65 \mathrm{~mm}$. The main ingredients found in the obtained oil include $\alpha$-citral $(27.982 \%)$ and $\beta$-citral (20.059\%), which are essential ingredients with high antibacterial properties against microorganisms.

\section{TABLE-2}

RESULTS OF THE ANTIBACTERIAL PROPERTIES OF THE ESSENTIAL OIL EXTRACTED FROM LEMON LEAVES OIL

\begin{tabular}{cc}
\hline Test bacterial & Antibacterial diameter $(\mathrm{mm})$ \\
\hline Pseudomonas aeruginosa & $14.00 \pm 2.65$ \\
Escherichia coli & $13.67 \pm 2.52$ \\
Staphylococcus aureus & $11.33 \pm 2.08$ \\
Bacillus cereus & $42.00 \pm 2.65$ \\
\hline
\end{tabular}

\section{Conclusion}

In this research, fresh lemon (Citrus aurantifolia) leaves were used as materials for extraction of essential oil using microwave assisted hydrodistillation method. In addition, chemical compositions and the antibacterial activities of the produced essential oil were assessed. GC-MS analyzed the chemical compositions of essential oil in lemon leaves showing that $\alpha$ citral (27.982 \%), $\beta$-citral (20.06 \%), D-limonene (15.73\%), acetic acid $(6.36 \%)$, nerol $(4.41 \%)$, nerol acetate $(3.49 \%)$, citronellol $(2.193 \%)$ and caryophyllene oxide $(2.01 \%)$ are the major constituents in the lemon leaves oil. Besides, essential oils extracted from the lemon leaves are resistant to the strain Bacillus cereus with a diameter of $42 \mathrm{~mm}$.

\section{ACKNOWLEDGEMENTS}

This research is funded by Nguyen Tat Thanh University, Ho Chi Minh City, Vietnam.

\section{CONFLICT OF INTEREST}

The authors declare that there is no conflict of interests regarding the publication of this article.

\section{REFERENCES}

1. H. Zhai, H. Liu, S. Wang, J. Wu and A.M. Kluenter, Animal Nutr., 4, 179 (2018) https://doi.org/10.1016/j.aninu.2018.01.005.

2. T.H. Tran, L.K. Ha, D.C. Nguyen, T.P. Dao, L.T.H. Nhan, D.H. Nguyen, T.D. Nguyen, D.V.N. Vo, Q.T. Tran and L.G. Bach, Processes, 7, 56 (2019); https://doi.org/10.3390/pr7020056.

3. T.K.T. Do, F. Hadji-Minaglou, S. Antoniotti and X. Fernandez, $\operatorname{Tr} A C$ Trends Anal. Chem., 66, 146 (2015); https://doi.org/10.1016/j.trac.2014.10.007.

4. T.H. Tran, H.H.H. Nguyen, D.C. Nguyen, T.Q. Nguyen, H. Tan, L.T.H. Nhan, D.H. Nguyen, L.D. Tran, S.T. Do and T.D. Nguyen, Processes, 6, 206 (2018); https://doi.org/10.3390/pr6110206.

5. R.C. Juliany, G.C. Philip, A.O. Corliss and C.R. Steven, Food Control, 54, 111 (2015); https://doi.org/10.1016/j.foodcont.2014.12.040.

6. T.H. Tran, P.T.N. Nguyen, V.T.T. Ho, T.H.N. Le, L.G. Bach and T.D. Nguyen, IOP Conf. Series Mater. Sci. Eng., 479, 012015 (2019); https://doi.org/10.1088/1757-899X/479/1/012015.
7. A. Nair S, R.K. Sr, A.S. Nair and S. Baby, Phytomedicine, 50, 231 (2018); https://doi.org/10.1016/j.phymed.2017.08.011.

8. M. Razzaghi-Abyaneh, M. Shams-Ghahfarokhi, M.-B. Rezaee, K. Jaimand, S. Alinezhad, R. Saberi and T. Yoshinari, Food Control, 20, 1018 (2009); https://doi.org/10.1016/j.foodcont.2008.12.007.

9. M.S.A. Aamri, N.M.A. Abousi, S.S.A. Jabri, T. Alam and S.A. Khan, J. Taibah Univ. Med. Sci., 13, 108 (2018); https://doi.org/10.1016/j.jtumed.2017.12.002.

10. S. Rafiq, R. Kaul, S.A. Sofi, N. Bashir, F. Nazir and G.A. Nayik, J. Saudi Soc. Agric. Sci., 17, 351 (2018); https://doi.org/10.1016/i.jssas.2016.07.006.

11. S.P. de Matos, L.G. Lucca and L.S. Koester, Talanta, 195, 204 (2019); https://doi.org/10.1016/j.talanta.2018.11.029.

12. S. Das, Z. Gazdag, L. Szente, M. Meggyes, G. Horváth, B. Lemli, S. Kunsági-Máté, M. Kuzma and T. Kõszegi, Food Chem., 278, 305 (2019); https://doi.org/10.1016/j.foodchem.2018.11.047.

13. F. Hojjati, H. Sereshti and M. Hojjati, Biochem. Syst. Ecol., 84, 29 (2019); https://doi.org/10.1016/i.bse.2019.03.004.

14. F. Yi, J. Sun, X. Bao, B. Ma and M. Sun, LWT-Food Sci. Technol., 102, 310 (2019); https://doi.org/10.1016/j.1wt.2018.12.051.

15. S.A. Khayyat and L.S. Roselin, J. Saudi Chem. Soc., 22, 855 (2018); https://doi.org/10.1016/j.jscs.2018.01.008.

16. J.M. del Valle, D. Calderón and G.A. Núñez, J. Supercrit. Fluids, 144, 108 (2019); https://doi.org/10.1016/j.supflu.2018.09.005.

17. G. Khalili, A. Mazloomifar, K. Larijani, M.S. Tehrani and P.A. Azar, Ind. Crops Prod., 119, 214 (2018); https://doi.org/10.1016/j.indcrop.2018.04.021.

18. D.S. Megawati, D.S. Fardhyanti, W.B. Sediawan and A. Hisyam, Ind. Crops Prod., 131, 315 (2019); https://doi.org/10.1016/j.indcrop.2019.01.067.

19. L.A. Conde-Hernández, J.R. Espinosa-Victoria and J.Á. Guerrero-Beltrán, J. Supercrit. Fluids, 127, 97 (2017); https://doi.org/10.1016/j.supflu.2017.03.026.

20. C. Dima and S. Dima, Curr. Opinion Food Sci., 5, 29 (2015); https://doi.org/10.1016/j.cofs.2015.07.003.

21. L. Espina, M. Somolinos, S. Lorán, P. Conchello, D. García and R. Pagán, Food Control, 22, 896 (2011); https://doi.org/10.1016/j.foodcont.2010.11.021.

22. P.Q. Tranchida, I. Bonaccorsi, P. Dugo, L. Mondello and G. Dugo, Flav. Fragr. J., 27, 98 (2012); https://doi.org/10.1002/ffj.2089.

23. G. Kirbaslar and S.I. Kirbaslar, J. Essent. Oil Res., 16, 105 (2004); https://doi.org/10.1080/10412905.2004.9698663.

24. D. Djenane, Foods, 4, 208 (2015); https://doi.org/10.3390/foods4020208.

25. L. Jing, Z. Lei, L. Li, R. Xie, W. Xi, Y. Guan, L.W. Sumner and Z. Zhou, J. Agric. Food Chem., 62, 3011 (2014); https://doi.org/10.1021/jf5006148.

26. S. Kamiyama, Agric. Biol. Chem., 31, 1091 (1967).

27. D. Hamdan, M.Z. El-Readi, A. Tahrani, F. Herrmann, D. Kaufmann, N. Farrag, A. El-Shazly and M. Wink, Food Chem., 127, 394 (2011); https://doi.org/10.1016/j.foodchem.2010.12.129.

28. L. Mondello, A. Cotroneo, G. Dugo and P. Dugo, J. Essent. Oil Res., 9, 495 (1997); https://doi.org/10.1080/10412905.1997.9700766.

29. Y. Huang, Z. Pu and Q. Chen, Perfum. Flavor, 25, 53 (2000).

30. B. Ifesan, J. Fashakin, F. Ebosele and A. Oyerinde, Eur. J. Med. Plants, 3, 465 (2013); https://doi.org/10.9734/EJMP/2013/3383.

31. M. Kivanç and A. Akgül, Flav. Fragr. J., 1, 175 (1986); https://doi.org/10.1002/ffj.2730010409.

32. N. Zandi-Sohani and L. Ramezani, Int. Biodeter. Biodegrad., 98, 101 (2015); https://doi.org/10.1016/j.ibiod.2014.12.007.

33. F.V. Leimann, O.H. Gonçalves, R.A.F. Machado and A. Bolzan, Mater. Sci. Eng. C, 29, 430 (2009); https://doi.org/10.1016/j.msec.2008.08.025.

34. M. de Paula Porto, G.N. da Silva, B.C.O. Luperini, T.F. Bachiega, J.P. de Castro Marcondes, J.M. Sforcin and D.M.F. Salvadori, Mol. Biol. Rep., 41, 7043 (2014); https://doi.org/10.1007/s11033-014-3657-9. 